\title{
Female Identity and Imposed Codes in Caroline Compson: The Influence of Utopia on a Mother
}

\author{
PhD. Dalila Karakaçi \\ "Luigj Gurakuqi" University, Shkoder, Albania \\ Email:karakacidalila@yahoo.com
}

\section{Doi:10.5901/ajis.2016.v5n3s1p43}

\begin{abstract}
This paper will be focused on the female identity and imposed codes in the character of Caroline Compson, in the novel "The Sound and the Fury", by William Faulkner. The complexity of her figure is evident in the whole novel. The characters her children expose in the story reflect the authority Caroline Compson had on their education. Faulkner creates an individual, symbol of a specific philosophy on the world, precisely that of the South America. Under the effect of cultural codes imposed by racial aggression, class superiority, she had to adapt to the rules of such reality. Caroline initiates a utopian image for her life and, above all, a utopian image for the behavior of every woman based on the cultural codes of such society and religious myth. They have imposed a motherhood utopia. Physical purity is the core of her entity, which is even emotional. Apart from love, negligence, deadly tyranny is hidden the failure of a woman. Buried in her utopia she abandons physical desire and the attention towards husband and children. Through an empirical analysis of Caroline Compson, I will arrive to the point to evaluate her identity and the codes that perturb her children and husband.
\end{abstract}

Keywords: Caroline Compson, female identity, codes, utopia, ideology

\section{Introduction: Utopia and Society}

If we horizontally and vertically analyze the ideas of utopia developed during the years and centuries, we will clearly understand a transformation, as they become part of the structure of life and contemporary experience. Manheim (1985) describes utopia as "a sort of passing orientation of the reality that at the same time rips the connections with that existing reality." (p.173) At the core of different concepts on utopia, which prevailed in the western societies, was the ideal creation of a society. This concept varies from the search for reflection over a better life, but it can even change to a pursue of impressions not based on reality, being just an immeasurable project of human mind. The meaning of the word utopia, of Greek origin, can be translated as eu-topia, a place finding happiness or as ou-topia, a place not based on reality, but a result of fantasy. (Manheim, p.173) Different supporters of utopia, such as Saint Thomas, Fourier (17721837) and Owen (1771-1858) had no intention to emancipate the specific classes, but humanity as a whole (Davis, 1984, 4). While Thomas Moore (1478-1535) in his book Utopia (1516), projects utopia as a way of thinking for different kinds of societies, maintains the notion of Manheim that a good living can be reached only outside the existing reality.

The political and social ideas exposed in The Republic (380 BC) by Plato (428/427 or 424/423 - 348/347 BCE), Metamorphosis (8 AD) by Ovid (43 BC- AD 17-18), The City of God (5 AD) by Saint Augustine (354 AD- 430 AD), are examples of the first steps of a utopian projection, followed by modernist satire. Davis (1984) differs utopia on four ideal societies: natural abundance, the idyllic, the perfect moral commonwealth and the man of millennium. (p.8-9) Davis hints that utopia represented by Thomas Moore "is a category of social idealism based on an organizational, legislative, administrative and educational detailed imagination." (p.10) Kumar (1987) is of the opinion that examples from myths of natural abundance, the idyllic or the man of millennium are an essential foundation in the long history of utopian ideas, presenting them as utopian occasions, but they are not utopia. At the same time, Kumar insists that Utopia by Thomas Moore is a result of a new period where rationalism and realism are typical of a classical revival of Renaissance."(p.21) Both Kumar and Manheim (1985) agree on the forms of a utopian mentality, supporting the idea that "modernist utopia changes when religious secularism is attached to the acting requests of the suppressed social strata." (p.190)

In Manheim's analysis on the four forms of utopian mentality is observed that overpowering secularism, which resulted in a second wave in the $18^{\text {th }}$ century, named as "liberal-humanist ideas" (p.197) were connected to the image of a politic and economic prosperity uttered by the idealist middle-class generation. Conservative ideas were the third form related to utopia, while being exposed in the capitalist economies and the republic states. Communist-socialist utopia is 
the fourth form articulated as a "new creation based on internal synthesis of different forms related to utopia, exposed up to now."(Manheim, p.215) Although criticizing socialist utopia, Engels (1880) is of the idea that socialist concepts widespread before Marx are utopian because they condemn exploitation, poverty, but create an equal, ideal society disappearing discrimination. In accordance with Engel, they remain utopian because are not able to explain the element of exploitation and the historical process producing capitalist inevitable fall "after that society's active forces act like nature's forces: blindly, destroying as much as it is impossible."(p. 73)

The discussion of Weber (1930) on utopia is more complicated and radical, saying that values do not exist in the social reality, even the result of a social action obfuscates the aim of the action and that the whole knowledge of the social world is just partial. (p.189) Weber's counter-utopianism changes from radical adaptations.

When God and faith become a meaningful urge to give meaning to man's life and help him face everyday problems, then faith takes a utopian connotation. This connotation is widespread in the context, where different religious preachers accept to leave apart the differences to bring peace and harmony through the formation of an existing utopian faith, just before the creation of universe. This concept of a far away future on faith forms the interfaith utopias. Members of a community fulfilling the rules imposed by the society form the intrafaith utopia. The Garden of Eden as well as Paradise is forms of utopia based on faith, found in different religions and preached in places where man finds peace, harmony away from sin, suffrage, misery, death.

A manifestation of utopia could be found within the context of myth. In many situations with human or superhuman creatures of a remote period, religious or secular archetypes, considered as a real overview of the manner the society and other natural phenomena were created. They present the living in the primitive form, but with emotional fulfilling, in full harmony of the man with the nature, avoiding the unnecessary wishes produced by conflicts and hostility. This simple and happy living has served as a reference for every crisis, with the hope that a near or far away future is the possibility to find happiness. What unites unlike mythic ideas and places is the expectation that such situation of happiness could be reached again.

If we focus on Lacan's psycho-analytic analysis, we could gather more information and explore the nature of utopia, its truthfulness. Lacan (2007) was of the idea that "the truth is the inability of the real knowledge on the other individuals, the inexistence coming from the absence of that relation, of the unreached situation, the inexistence of a place."(p.89) In these terms, the inexistence of a place indicates not only that this place does not exist, but at the same time, implies an ideal one, unreachable because perfect. The truth is imposed on humanity; giving a possibility to face the hidden, suppressed, unspoken feelings, affecting the normal progress of the individuals, save for suppressed groups. There exist a double result in this confrontation, on one side is an ideal society, if the confrontation is achieved, on the other side the utopia may be denied, if the confrontation is not achieved and the truth is covered. Utopia does not treat issues or places far away from the individual or community; in contrast, the hollow space between utopia and the subject is too close.

\section{An Indirect Reflection of Mrs. Compson's Character}

In the novel, Mrs. Compson, is exposed as a complex character. Her representation is achieved through the description and characterization made by Quentin, Benjy, and Jason. The figure of the three brothers in the novel reflects even the influence of Mrs. Compson, their mother, during childhood, adolescence and maturity. In his episode, Quentin, remembers details from his mother reflecting their relation together with her influence on his personality. In the whole episode exists repetition of the same key motif: "If I could say Mother."(Faulkner, 1990, p.117) This motif is abundant in the whole episode, while increasing the emotional bond: reader-novel, but even the psychological tone. The motif appears for the first time in a conversation between Mrs. Compson and Herbert Hedin, in April 1910:

Why shouldn't you want my boys to be more than friends yes Candace and Quentin more than friends Father I have committed what a pity you had no brother or sister No sister no sister had no sister Dont ask Quentin he and Mr Compson both feel a little insulted when I am strong enough to come down to the table I am going on nerve now l'll pay for it after it's all over and you have taken my little daughter away from me My little sister had no. If I could say Mother. Mother

Ah Herbert Candace do you hear that She wouldn't look at me soft stubborn jaw-angle not back-looking You needn't be jealous though it's just an old woman he's flattering a grown married daughter I cant believe it.

Nonsense you look like a girl you are losts younger than Candace colour in your cheeks like a girl A face reproachful tearful an odour of camphor and of tears a voice weeping steadily and softly beyonf the twilit door the twilight-coloured smell of honeysuckle. Bringing empty trucks down on the attic stairs they sounded like coffins French Lick. Found not death at the salt lick (p.117) 
Even in the last part of his episode, Quentin refers to the relation with his mother: "the first car in town a girl Girl that's what Jason couldn't bear smell of gasoline making him sick then got madder than ever because a girl Girl had no sister but Benjamin Benjamin the child of my sorrowful if l'd just had a mother so I could say Mother Mother" (p.213) A turmoil interaction is evident in these words involving the mother and the son. A son laments the spiritual loss of a mother, who seems to have abandoned his child's education. It is created the impression that this mother has not given Quentin and his brothers the sublime love and encouraging strength, characteristic of mothers. From a detailed description of memories haunting Quentin, we could typify Mrs. Compson, judge an aged woman flirting with her daughter's fiancé, waiting to be in the center of attention without being disturbed by the consequences her behavior has on her children. She is always hiding through the tears her marriage consequences.

From the beginning of Benjy's episode, Mrs. Compson, is present, but always accompanied by her brother, Maury.

"Let him go, Caroline." Uncle Mary said.

"You'll worr yourself sick over him."

"Iknow it." Mother said. "lt's judgement on me. I sometimes wonder"

"I know, I know." Uncle Maury said. "You must keep your strength up. I'll make you a toddy." (p.4)

Save for uncommon moments is felt the presence of Mr. and Mrs. Compson, as a couple, running the family and taking care of their children. Maury's existence is imposing in the Compson family. It is created the impression that he is in the middle of the couple, accentuating their alienation. Their durable relation looks as if surpassing a common brothersister bond, implying a forbidden incest. The appeal for refusing his husband's surname, to become closer to the family of origin, intensifies the bond between her and the brother.

\section{Mrs.Compson's Cultural Codes and Utopia}

In the novel is noticed, indirectly, from the actions described by Compson's children, a disharmony between Mr. and Mrs.Compson. Mrs. Compson's life is divided in two parts: the first part belongs to a young Mrs. Compson, living the life of a beautiful and desirable youthful lady, ready to be married; the second part, after marriage, is focused on having children and the marriage miscarriage weeping. The codes of the society have imposed a utopia on the role of females in South American, and more specifically on Mrs. Compson's role within the family. Her utopia was to stay virgin till her marriage. After exploring her female libido, when getting married and getting pregnant with four children, her life enters a period of permanent stagnation, followed by the abandonment of her children and husband. Faulkner creates a figure that does not move, but is stuck within her social environment. She seems to have fulfilled her family obligations along with her female utopia, affected by social conditions and the actual situation of women's emancipation. The accomplishment of her youthful fantasies causes her stagnation, illness, and neglect of her responsibilities. In a particular moment, she even tries to explain not only her utopia but the utopia she thinks pertain to the whole women of $20^{\text {th }}$ century American society.

"Yes," Mother says, "I suppose women who saty shut up like I do have no idea what goes on in this town."

"Yes," I says, "They don't."

"My life has been so different from that," Mother says. "Thank God I don't know about such wickedness. I don't even want

to know about it. I'm not like most people." (p.323)

While questioning the cultural codes and their impact in the formation of an individual's personality, and style of living, Roland Barthes (1977) hints that "if we achieve to get all this knowledge, these vulgarities we create a monster named ideology."(p.204) Mrs. Compson is a representative of individuals generated by the ideology of the American society and the cultural codes related to it. Faulkner produces a symbolic figure that does not only play the part of a specific character, but also represents a particular philosophy on the world, more explicitly that of South America. Under the influence of a society, where its codes were based on racial and class aggression, the cotton growers had the economic power, social dominance, while over putting their rules on the lower class, Mrs. Compson had to adapt to the regulations compelled by this reality. She originates a utopian image for her life and above all a utopian image for the conduct of every woman based on the cultural codes she was living. Within such background, the most important code was the preservation of moral and physical purity. In Quentin's episode, as describing the codes she is brought up and have influenced her utopia, she contrasts herself with her daughter. 
baby girl she is she is no better than that when I was a girl I was unfortunate I was only a Bascomb I was taught that there is no halfway ground that a woman is either a lady or not but I never dreamed when I held her in my arms that any daughter of mine could let herself don't you (p.127)

Her physical purity is even symbolic. Mrs. Compson is snuggled in her image created during the early years of her life and she did not achieve to adapt to different social, economic, and cultural realities of the time living. She has no knowledge on business deals, on the usage of bank cheque, the behavior of women in society, how they pass their free time, what are their activities, their relation to men, how to deal with their intimacy. On the contrary, she locked herself up in an existential utopia causing troubles. The crying, illness, inactivity, inattention against children and her husband are the result of a mistaken utopia. Many critics blame Mr. Compson for his negligence in the education of children. John Irwin (1975) hints, "everything found in Mr. Compson's perception of a society, based on symbolic fantasy of traditional notions on morality and virginity, does not exist anymore. He is attached to this system as a structure produced by it, not as an unchangeable essence, but for her wife this is the core of herself." (p.120-22). It is precisely Mrs. Compson who does not accept to suit to the social changes and get out of her existential fantasy persuaded by the social environment, to live life for herself, her children, and her husband.

She seems to have fulfilled her utopia. The result of this fulfillment is her lost: physically, mentally. The lost of virginity together with the birth of her children constitutes the fulfillment of her utopian image formed by cultural social codes. It is inferred that in this culture is not included the attention and care for children, but absolute negligence. The imposition of these rules on her children brought up their frustration. All her codes turn out to be a mere alienation of the motherly codes. In many episodes are observed such qualities, especially in that of Quentin. Through eruption of the traditional exposure of action in the story, and using memory reminiscences of moments with his mother, Quentin blames her for his mental confinement. This mother misses love, sweetness, spiritual bond, motherhood, but generates coldness, insecurity, and physical motherhood. For Quentin, she is the darkness her spirit is sank:

\begin{abstract}
You know what l'd do if I were King? She never was a qween or a fairy she was always a king or a giant or a general l'd break that place open and drag them out and l'd whip them good It was torn out, jagged. I was glad. l'd have to turn back to it until the dungeon was Mother herself she and Father upward into weak light holding hands and us lost somewhere below even them without even a ray of light. (p.215)
\end{abstract}

The same imprisonment is over lived even by Jason, while asking her mother the keys to Quentin's room. In a scene is understood the effort of a child to get the key of the mother to free himself from her symbolic prison, in order to find salvation: "Give me the key, you old fool!" Jason cried suddenly. From her pocket he tugged a huge bunch of rusted keys on an iron ring like a mediaeval jailer's and ran back up the hall with the two women behind me." (p.331) Quentin and Jason are conscious of the spiritual frustration and lost of themselves caused by maternal abandonment. The abandonment is replaced by the perseverance to teach even her children the same rules and codes that made Mrs. Compson's life. This results in a failure of maternal relations between children-mother, starting from the failure of Mrs. Compson in creating maternal relations with her children to the failure of Caddy, and the least but not the last, the failure of Miss Compson, who throws away the idea of ever having children. Such conduct is a result of the utopia influenced by the society.

Cultural codes have imposed a maternal utopia. Every woman valuable for the society must have her sole fantasy marriage and propagation, avoiding any other possible desire. Through building a figure as a synthesis, Faulkner transmits generalizing ideas within specific social connotation. The whole middle-class society has got as a maternal myth that of pious woman: the Virgin Mary. Such presupposition underlies the supposition of all women behaving under this influence. Based on such assumption, all women must follow Virgin Mary's three virtues: that of silence, assistance towards the others, and virginity. Mrs. Compson bases her utopia just on the third virtue: virginity. This utopia imposed by the society, not derived from her free will, is rooted in the physical process of giving birth to the heirs for the Compson family. She dedicates no attention to her female libido, but shows contempt against the sexual appreciation of her body. In the middle class society, women, should not dedicate attention to their libido.

The American society was not, yet, ready for a sexual revolution, even the majority of women were not ready to start and support this movement. This is the motive why Mrs. Compson is a representative of many women educated by the social codes related to religious myth. They build their utopia on the myth of physical purity, which appears to be still emotional. Her identity is related to the religious myth. After fulfilling her utopia, Mrs. Compson uses her as a manner to hide the reality. She evades the responsibility from Benjy's mental illness; hides from the sexual reality of Caddy, a woman of different desires as well as fantasies, who will suffer like her mother the emancipated social reality; escapes 
the maternal parenting for Quentin. The sole member of the Compson family fulfilling her fantasy is Jason who, from her view point, is more Bascomb than Compson. No seed of Compson has penetrated Jason. During his birth she was still virgin, like Virgin Mary.

\section{Conclusions}

The maternal utopia divides females in two roles. In the first role, females should act according to the virgin utopia, renouncing the sexual desires. In the second role, females should act according to an alienating utopia, derived from the desires inflicted by the body. As I mentioned above, Mrs. Compson was of the idea that the bodily treasures were unacceptable from, the so called, ladies of high society. If a girl wanted to be "a lady", or part of the high society, they had to abandon bodily desires, because its purpose was just to dedicate to the process of propagation. Within this utopian line of thought, virgin females are described as imprisoned within their desires, frustrated, toward a slow agony of physical death, because the spiritual death has already occurred. The whole being of these women dies when they give birth to heirs. An example of these women is definitely Mrs. Compson. On the other hand, the women of physical desire loose the right to be called ladies by the society, since they enliven their sexuality within constraints. They are a property of their fathers, brothers or husbands. Mainly young women, they break the imposed utopia. A typical representative of these women is, of course, Caddy, Mrs.Compson's daughter.

Our perception of Mrs. Compson, is achieved through the descriptions and judgments made by her children. Over the indiscretion, love, compassion and tyranny is hidden the failure of a woman. She has built a jail with her utopia not only for her children, but even for herself. Immured in her utopia, she abandons her bodily desires and the parenting of her husband and children. Motherhood is her fantasy, desire, but even her destruction.

\section{References}

Adorno, Th. \&Horkheimer, M.(1997).Dialectic of Englightment. New York:Verso Books.

Barthes, R.(1977).Roland Barthes by Roland Barthes. New York: Straus \& Giroux.

Davis, J.C.(1984).Utopia and Ideal Society: A Study of Utopian English Writing. Cambridge University Press.

Engels, F.(2013). Socialism: Utopian and Scientific. Waxkeep Publishing

Faulkner, W. (1990). The Sound and the Fury. New York: Vintage International.

Irwin, J.(1975). Doubling and Incest, Repetition and Revenge: A Speculative Reading of Faulkner. Baltimore: John Hopkins.

Kumar, K.(1987).Utopia and Anti-utopia in Modern Times. Blackwell Publishers.

Lacan, J.(2007). The Seminars of Jacques Lcan: The Other Side of Psychoanalysis. New York: RusselGrigg.

Manheim, K.(1985). Ideology and utopia: An Introduction to the Sociology of Knowledge. New York: Mariner Books.

Moore, T. (1949). Utopia. Harlan Davidson Inc.: Arlington Heights.

Plato, (2008). The Republic. Oxford University Press.

Weber, M.(2012). The Protestant Ethic and the Spirit of Capitalism. North Carleston: Independent Publishin Platform. 